Int.J. Hum. Soc. Dev. Res.

ISSN (P):2521-1439; ISSN (E):2523-4331

Volume 3, № 2, 2019. 65-73

DOI:10.30546/2523-4331.2019.3.2.65

\title{
EMPOWERMENT OF VILLAGE ADMINISTRATION WITH CUSTOMARY LAW (ADAT) IN NORTH SUMATRA
}

\author{
Taufik SIREGAR \\ Universitas Medan Area, Indonesia
}

(C) The Author(s) 2019

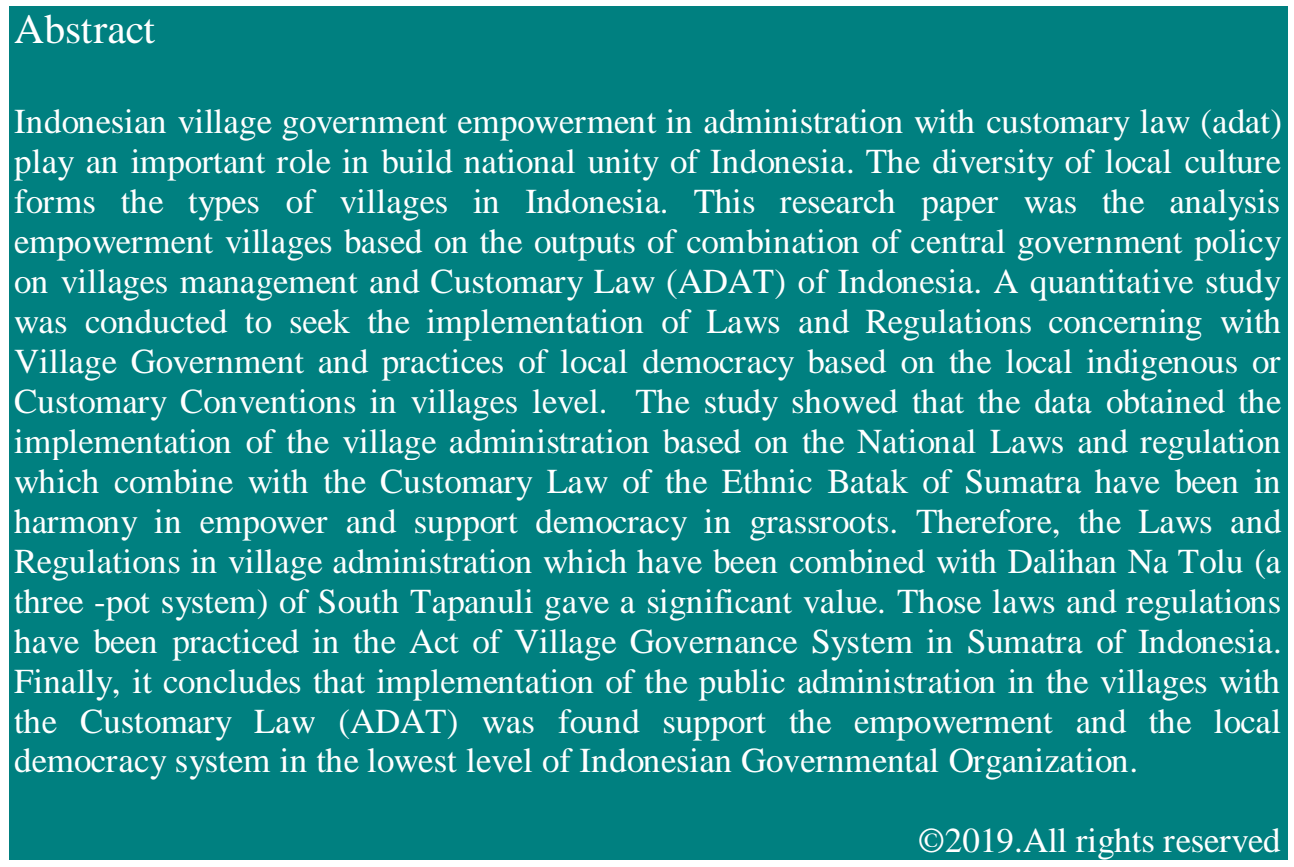

\section{ARTICLE HISTORY}

Received: 18/02/2019

Accepted: 11/07/2019

Published online: 03/10/2019

\section{KEYWORDS}

Village, Desa, empowerment; customary law; governance 


\section{Introduction}

Indonesia has many forms of villages such as Desa, Desa Adat, Banjar, Huta, Kampung/Gampong and Nagari. Generally village is defined as the collection of community placement area that has its own customs rules with various devices used to regulate various aspects of life. In rural communities in safeguarding the rights and responsibilities of the public a village government is to guarantee the safety and public peace. Other may conceptualize the village as a number of placements in rural areas. A village is a collection of some of the placement units called Desa of Malay, Gampong /Kampong of Aceh, Huta of Tapanuli, Banjar of Bali as well as Nagari of West Sumatra. Regarding to village government, the implementation of Article 18 paragraph (6) of the 1945 Constitution Indonesian makes the Provincial and Local Governments of Indonesia have specific right to set local regulations or other regulations to carry out the task of autonomy as mentioned in Indonesian Law No. 19 of 1965 About Desapraja (Villages Autonomy), Law No. 5 of 1979 on Village Governance, Law No. 22 of 1999 on Regional autonomy, Law No. 32 Year 2004 on Regional Autonomy Law Number 72 Year 2005 on the village government. It may say that the village governments have specific rights to execute public services in their territories. It could be said that local governments with adoption of customary traditions may combine the Laws and Regulations of Central Government to manage political, social and economic sectors of villages' rural areas in Indonesia.

Furthermore, the provision of article 1 numbers 5 of Indonesian Law No. 72 Year 2005 regulates that the villages or as called by other names, hereinafter referred to as the village is a legal community unit which has boundaries that are authorized to regulate and manage the interests of local communities, based origin and local customs that recognized and respected 
in the system of government of the Republic of Indonesia (NKRI). Since the regional autonomy. The term of village can be called by other names, for example, in West Sumatra called the Nagari, or in Aceh is so called Gampong/Kampong.

Similarly, the diversed local cultures of Indonesia made the local governments have rights to name the villages in accordance with the characteristics of the customs of the local communities. This is an acknowledgment and respects the past Kingdoms before the National Independence of Indonesia in 1945. The role of indigenous value systems, such as the Dalihan na Tolu (a tree pot system) of Ethnic Batak in South Tapanuli involves three elements of traditional philosophy Dalihan na Tolu as executors of culture and Chief of Huta (village) in the governance administration. Conception of a tree pot system of Ethnic Batak. Implementation of the public administration in the villages of Batak may combine local tradition. This research was conducted to find the specific model of combinational National Regulation of Indonesian Law of village government and local democracy. It took the implementation of village government in Batak society of North Sumatra.

\section{Design of Research}

A Qualitative Design (Cox, Geisen, and Green, 2008) was applied to investigate the combination of two sources of village management system; The study for the local government with the Indonesian Laws and Regulations analysis and practices of democracy in villages level is very interesting. The research aimed at seeking the social facts of Huta (village) Government in South Tapanul which has Customary Law (ADAT) of Dalihan $\mathrm{Na}$ Tolu System of social indications. This study made investigator set of questions of instruments which was spread to various areas in North Sumatra. It took the village governance system which has 
been exercises at the village level. It took values as collection of life reflection of villagers who settled in their own customary law. The village administration as the power media of head of village meets the traditional village leadership structure; each village is led by a King (Pamusuk) of local kings (Federation of local kings is led by the King Pamusuk) of Ethnic Batak in South Tapanuli. This study used the system deliberation held in any decision-making at the village administration in Ethnic Batak of South Tapanuli of North Sumatra which has been imbued in the values system of Customary Law of Dalihan na Tolu.

\section{Findings and Discussions}

This research found the condition of public policy of village governance in North Sumatra of Indonesia. According to Government Regulation Number 72 of 2005 concerning Villages, it is said that the Village is a legal community unit that has territorial boundaries that are authorized to regulate and administer the interests of the local community, based on local origins and customs that are recognized and respected in the Republican Government system Indonesia. The Previously Regional Government Law ( Law No. 32/2004) in Article 206, it only divided the authority of government affairs which became the village's authority. Based on this provision, it can be seen that the emphasis of Law No. 32/2004 did not specifically give attention to village authority, but rather gave emphasis to the division of government affairs alone.

The current division of government affairs, and their relationship to village authority, can be seen in Law no. 23/2014 concerning Regional Government which states that Government Affairs are divided into three, namely: Absolute affairs, Concurrent affairs and General Affairs. Absolute affairs are matters which only fall under the authority of the Central Government; Concurrent affairs are central government affairs that can be 
delegated to Provincial Governments; and General Affairs are public services carried out by the President's authority. In that public functional, Village Governments can carry out concurrent functions carried out that pass by the Regency or City Government based on the Governor's regulation if the Provincial Government and Regents give the tasks to Village Governments.

Additionally, in the 1945 Indonesian Constitution of chapter 18, paragraph 6; Law No. 19 of 1965 About Desapraja, (2) of Law No. 5 of 1979 on Village Governance, (3) of Law No. 22 of 1999 on Regional Autonomy, (4) of Law No. 32 Year 2004 on Regional Autonomy, (5) of Law Number 72 Year 2005 on the village. Indonesia has a diverse system in the implementation of its administration possessed value valuation basis. Government of villages performance based on Laws and local wisdom. The indigenous valeus of Dalihan $\mathrm{Na}$ Tolu have been formalized by Council of Villages and Goverment; by the laws and regulations set forth in Rule in Tapanuli in 1990 concerning with local Institute Dalihan Natolu, which is a traditional institution established in Local Government Level II; as an institution of deliberations that included indigenous elders who truly understand, master and appreciate the customs. (Case 5 and 8 Regulation No. 10 of 1990). This institution has a duty to carry out various efforts in order to grow, maintain, preserve and develop the culture of the area including the customs and arts for the purpose of development in the local kingdom system of villages in South Tapanuli in Article 6 of the Regulation No. 10 of 1990.

\section{Discussion}

The types of villages in Indonesia could be analyzed from Sociological, Economic, and Political perspectives. Maschab (2013) argued that the villages in Indonesia, then at least three kinds of interpretations will 
arise. First, sociological morphology of villages dealt with a form of community unity who settles in an environment. It shows villagers interaction; know each other well and their life style is relatively homogeneous, and much depends on the goodness of nature. In the understanding of the sociology, the village is associated with a community that lives simply, generally lives from the agricultural sector, has strong social ties and customs or traditions, is honest and unpretentious; its education is relatively low and so forth. Second, in the economic sense, the village as a community environment that seeks to meet the daily living needs of what is provided by the natural surroundings. In this second sense, the village is an economic environment, where residents try to meet their daily needs. Third, political understanding, wherein 'the village as a government or power organization that politically has a certain authority because it is part of the state government.

In empowering village government, it is led by the village head or could be called by another name assisted by the village apparatus as an element of the village administration. It has a Council of Village could be so-called by other names is an institution that carries out government functions whose members are representatives of the villagers based on regional representation and are democratically determined. Empowerment of village Community is an institution formed by the community in accordance with needs and is a government partner in empowering the community. Legal culture of village government may be found in all forms of human cultural behavior affecting or relating to legal issues. It is not only legal in the sense and forms of behavior as a habit that repeatedly occur, as in customary law, or law within the meaning and form (regulations, standards, provisions) legislation, which is called legal with normative approaches. It deals with the legal issues that are viewed from aspects such as intellectual, philosophy, psychology and others, as well as ways to solve disputes that arise in the community. 
Indonesia has some regulations of village government such as : Law no. 22 of 1999 which states :"The village is a legal community unit that has the authority to regulate and manage the interests of the local community based on local origins and customs that are recognized in the National government system and are in the Regency area".

Indonesian Law no. 5 of 1979 states : "Village is an area occupied by a number of residents as a community unit, including a legal community unit that has the lowest government organization directly under the District Head and has the right to organize its own household in the ties of the Unitary Republic of Indonesia”. Indonesian Law no. 6 of 2014: “ Local Government is a Desa and a customary village or what is referred to by another name, hereinafter referred to as Village, is a legal community unit that has the authority to manage and manage government affairs, the interests of the local community based on community initiatives, original rights, and / or traditional rights which is recognized and respected in the government system of the Unitary Republic of Indonesia". Through the principle of recognition and subsidiarity, Law no. 6 of 2014 concerning Village Law carries the spirit of strengthening the Village as an independent entity, which is an entity that can carry out its own affairs without excessive interference from the government.

In regulating its own affairs, the village is given the authority to organize village governance based on democratic principles, namely villagers who have the right to be involved in the administration of the government. Proposed democracy system in village government is not formal democracy as practiced at the state level, with political parties as the main instrument. Village Democracy is understood here as a practice that promotes consensus in every decision-making process, which involves villagers directly or through representative institutions. The practice of village 
democracy as mandated by the Village Law does not involve political parties as citizens' representations, but it is carried out by the Village Consultative Body (BPD). In this context, BPD empowerment is important in order to strengthen village government. This village is often referred to the State Laws and Cutomary law (ADAT) in manage the Village Government. The type of village autonomy management is now could be combined by the Indonesian laws and local traditions which empower it and grow the village democracy.

\section{Conclusions}

Data analysis gives two conclusions of empowerment of village government with Customary Law (ADAT) of South Tapanuli of Indonesia; (1). Indonesian village government has a clear institutional structure, including staff and secretarial support. The Desa (village) may called by another name that is very diverse in Indonesia, was originally a local community organization that has territorial boundaries, is inhabited by a number of residents, and has a customary tradition to manage itself called the self-governing community.

(2). Village Government roles and its functions has been categorized into three types. First, the Desa Adat (self-governing community); second, the Autonomous Village (local self-government). Third, Administrative Village, a subsystem of the district or city government. Adoption of Dalihan Na tolu system in Huta (Village) Government in South Tapanuli of Sumatra supports the Adminsitration of Huta Government with Customary Law (ADAT).

\section{Disclosure statement}

No potential conflict of interest was reported by the author. 


\section{References and notes:}

Cox, Pat, Giesen Thomas, and Green, Roger (2008). Qualitative Reserach and Social Change: European Contexts, New York: Palragve Macmilan.

Maschab, Mashuri Mashab (2013), Village Politics of Villages in Indonesia, First Edition, PolGov FISIPOL Universitas Gajah Mada, Yogyakarta, 2013, Pp. 1-2

Yasin, Muhammad, et al. (2015). Anotasi Undang-Undang No. 6 Tahun 2014 tentang Desa. Pattiro Jakarta Laws and Regulation of Indonesian Government (PP) Indonesian Constitution 1945;

Indonesia Law No. 19 of 1965 About Desapraja;

Indonesia Law No. 5 of 1979 on Village Governance;

Indonesia Law Nomor 12 Tahun 2011 tentang Pembentukan Peraturan Perundangundangan.

Indonesia Law No. 22 of 1999 on Regional Autonomy,

Indonesia Law No. 32 Year 2004 on Regional Autonomy,

Indonesia Law Number 72 Year 2005 on the village

Indonesia Law No 6 year 2014 About Villages

Indonesian Government Regulation (PP) No. 43 Year 2014 , which has been revised in No. 47 Year 2015 Concerning with Implementation of Law No 6 Year 2014 Concerning with Village

Mnistry of Home Affairs of Indonesia No 84 Year 2015 Concerning with Organization Structure and Governance of Village Government

The Regulation No. 10 of 1990 of Villages in South Tapanuli

\section{Contact Information}

E-mail: saiful@fkip.uisu.ac.id 